\title{
Intracellular Acid-Base Relations of Dog Brain with Reference to the Brain Extracellular Volume *
}

\author{
Robert F. Kibler, † Richard P. O’Neill, \\ (From the Department of Medicine, University of Pittsburgh School of Medicine,
} Pittsburgh, Pa.)

There is now abundant evidence that a substantial hydrogen ion gradient exists between extracellular and intracellular water. The mechanism maintaining this gradient is not known, but for most cells it does not appear to be a function of simple Gibbs-Donnan equilibrium. Moreover, under a variety of circumstances, changes in the $\mathrm{pH}$ of one fluid compartment may occur without producing comparable changes in the other (1). Apparently, therefore, studies of acid-base metabolism cannot be restricted just to a consideration of extracellular hydrogen ion concentration but should include independent estimates of the $\mathrm{pH}$ changes within cells.

In vivo studies of intracellular $\mathrm{pH}$ in the mammalian species have dealt largely with muscle and erythrocytes. Recently, estimates of whole body intracellular $\mathrm{pH}$ have been made in dogs and in humans by the 5,5-dimethyl-2,4-oxazolidinedione (DMO) technique $(2,3)$, and the $\mathrm{pH}$ of brain cells has been measured in rats by the $\mathrm{H}_{2} \mathrm{CO}_{3}$ $\mathrm{HCO}_{3}{ }^{-}$system (4). However, no systematic study has appeared concerning acid-base regulation in brain cells. In our study the effects of various experimental modifications of extracellular $\mathrm{pH}$ on the intracellular $\mathrm{pH}$ of brain have been determined in dogs by the DMO technique.

The DMO method, first introduced by Waddell and Butler for the indirect measurement of the internal $\mathrm{pH}$ of muscle cells (5), requires an estimate of the extracellular fluid volume (ECF) of the tissue under study. As there is no general agreement concerning the magnitude of brain

* Submitted for publication March 18, 1963 ; accepted November 14, 1963.

Supported by U. S. Public Health grant H-05059.

Part of this work has appeared in abstract form, J. clin. Invest. 1962, 41, 1371.

$\dagger$ Present address: Department of Medicine, Section of Neurology, Emory University School of Medicine, Atlanta, Ga.

$\ddagger$ U. S. Public Health Service fellow.
ECF nor any agreement concerning the substance to be used in determining brain ECF, we used both endogenous chloride and radiolabeled sulfate spaces as estimates of the extracellular fluid space of the brain. The data obtained in these studies have proven to be relevant not only to acid-base metabolism in the brain but also to the problem of the magnitude of brain extracellular volume.

\section{Materials and Methods}

Dog experiments. Forty-three adult, mongrel dogs weighing between 10 and $14 \mathrm{~kg}$ were studied. Each dog was anesthetized with sodium phenobarbital in a dose of $125 \mathrm{mg}$ per $\mathrm{kg}$. After insertion of an endotracheal tube, spontaneous ventilation was abolished with iv succinyl choline and artificial ventilation maintained with either an Etsten or Harvard pump set to deliver approximately $4 \mathrm{~L}$ of room air per minute. The kidneys were mobilized through an extraperitoneal approach, and the renal pedicles, including blood vessels and ureters, were ligated. Indwelling polyethylene catheters were placed in a femoral artery and an external jugular vein. The animal's scalp and underlying musculature were "peeled" off the skull, and the left posterior aspect of the bony calvaria was rongeured away. After the exposed dura was excised, from the occipital pole of the left cerebral hemisphere approximately three $g$ of tissue was dissected with a sharp knife. Gel foam was placed in the wound and the cranial defect covered with dry gauze. Bleeding eventually stopped spontaneously after an estimated blood loss of approximately $15 \mathrm{ml}$. Simultaneous with biopsy of the brain, $30 \mathrm{ml}$ of heparinized arterial blood was collected for chemical analysis. Over a 10 minute period $1.5 \mathrm{~g}$ DMO in $30 \mathrm{ml}$ of $5 \%$ glucose in water and, in some dogs, $5 \mathrm{mc}$ of $\mathrm{Na}_{2} \mathrm{~S}^{35} \mathrm{O}_{4}$ were injected intravenously. The end of the injection was designated as " 0 " time. Four hours later approximately $3 \mathrm{~g}$ of tissue from the right occipital pole was removed in a manner similar to that on the left, and a second simultaneous $30-\mathrm{ml}$ sample of heparinized arterial blood was obtained. DMO has been shown to equilibrate with muscle within 1 hour (5) and to reach equilibrium throughout total body water by the end of 3 hours (2).

In 4 animals the rate of equilibration of DMO in muscle water and brain water was determined. After the infusion of $1.5 \mathrm{~g}$ of DMO in $30 \mathrm{ml}$ of $5 \%$ glucose in 
water, sequential samples of plasma, muscle, and brain were obtained for periods up to 3 hours. These samples were analyzed for total DMO concentration.

In 11 animals the rate of achievement of a steady state $\mathrm{S}^{35} \mathrm{O}_{\sharp}$ distribution between plasma and brain water was determined. After the iv injection of $5 \mathrm{mc}$ of $\mathrm{Na}_{2} \mathrm{~S}^{35} \mathrm{O}_{4}$, sequential samples of plasma and of brain were obtained for periods up to 12 hours. These samples were analyzed for radioactivity, and sulfate was calculated (see below ).

The remaining animals were divided into 5 groups. Seven dogs served as controls and received a $200-\mathrm{ml}$ infusion of $5 \%$ glucose in water over a 30 -minute period. The next 3 groups of animals received a mineral acid or base administered intravenously in $200 \mathrm{ml}$ of $5 \%$ glucose in water over a 30-minute period; 6 dogs received 150 mmoles $\mathrm{NaHCO}_{3}$ each, 4 dogs received $150 \mathrm{mEq}$ Tris [tris (hydroxymethyl)aminomethane] each, and 6 dogs received $30 \mathrm{mEq} \mathrm{HCl}$ each. A fifth group of 5 dogs was exposed to a mixture of $10 \% \mathrm{CO}_{2}$ and $90 \% \mathrm{O}_{2}$ for 1 hour. At the end of the fifth hour of the experiment, or one-half hour from the completion of the infusions and at the end of the period of $\mathrm{CO}_{2}$ inhalation, the right frontal pole of the brain was removed simultaneously with a third, $30-\mathrm{ml}$ sample of heparinized arterial blood.

In some dogs, one or more adjustments in the volume of minute ventilation were required during the initial portion of the experiment to bring the plasma $\mathrm{pH}$ within the normal range. Arterial blood pressure was monitored throughout the experiment to maintain the mean arterial pressure above $60 \mathrm{~mm} \mathrm{Hg}$.

I)ctcrmination of plasma $\mathrm{pH}$ and $\mathrm{Pco}_{2}$. Arterial blood drawn under oil in a heparinized syringe was used for both measurements. Plasma $\mathrm{pH}$ was determined anaerobically with a $\mathrm{H}^{+}$sensitive glass electrode at $38^{\circ} \mathrm{C.}{ }^{1}$ The $\mathrm{PCO}_{2}$ of plasma was measured under anaerobic conditions with a Severinghaus electrode.

Preparation of brain samples for analysis. As soon as each brain biopsy had been obtained, the leptomeninges were removed, and the surface of the sample was blotted on dry gauze. Davson and Spaziani (6) have found with the use of $\mathrm{Cr}^{51}$-labeled red cells that there are $1.2 \mathrm{ml}$ of blood in $100 \mathrm{~g}$ of brain. Woodbury (7) has estimated that samples of rat brain handled in a manner similar to that used in these studies are contaminated with less than $0.1 \%$ whole blood. Therefore, the blood in the brain samples was ignored in the subsequent calculations. A $0.5 \mathrm{~g}$ portion of each sample was dried for 1 week at 80 to $90^{\circ} \mathrm{C}$. Preliminary experiments had indicated that drying of the specimen was complete at this temperature in 4 to 5 days. The remaining weighed portion of brain (from 2 to $4 \mathrm{~g}$ ) was homogenized with 10 to $15 \mathrm{ml}$ of distilled water in a Servall omni-mix at high speed for several 1-minute periods.

DMO content of plasma and brain homogenate. A modification of Butler's method (8) for the analysis of DMO in plasma was used, and all determinations were

1 Instrumentation Laboratory Inc., Boston, Mass. done in duplicate. A 1-ml sample of plasma, diluted $1: 5$ with distilled water, or a weighed, 1-ml portion of brain homogenate, was mixed with $4 \mathrm{ml}$ of $5 \mathrm{M}$ $\mathrm{NaH}_{2} \mathrm{PO}_{4}$ and $25 \mathrm{ml}$ of anhydrous ethyl ether. After centrifugation, $20 \mathrm{ml}$ of the ether phase was transferred to tubes containing $5 \mathrm{ml}$ of $0.05 \mathrm{M}$ borate buffer, $\mathrm{pH}$ 9, previously saturated with ether. After mixing and centrifugation, a sample of the lower (aqueous) phase was removed and the difference in absorption at $215 \mathrm{~m} \mu$ and $220 \mathrm{~m} \mu$ read in a Beckman DU spectrophotometer. A standard curve was determined anew for each experiment and the total DMO concentration (milligrams per liter) in plasma and brain homogenate calculated from this curve. Preliminary experiments had shown that normal dog brain contains a substance indistinguishable from DMO when analyzed in the above manner. ${ }^{2}$ Hence, a DMO determination was done on each control sample of brain obtained before the administration of DMO, and this value was then substracted from the total amount of DMO in subsequent samples. The amount of "DMO" in the control samples averaged $65 \mathrm{mg}$ per $\mathrm{L}$, or $25 \%$ of the DMO concentration of the 4-hour brain samples. In 2 separate experiments, DMO was added to a homogenate of control brain to provide a concentration of 30,60 , and $90 \mathrm{mg}$ per $\mathrm{L}$ of brain homogenate. The percentages of recoveries of DMO from these specimens were 102,98 , and 95 , respectively. Other preliminary experiments have shown that correction of the optical density readings for the presence of barbiturate in the plasma and brain do not significantly alter the results.

1)ctermination of chloride and sulfate spaces of brain. The chloride concentrations of plasma and of a Somogyi filtrate of brain homogenate were measured in a chloridometer ${ }^{3}$ by the electrometric titration technique of

2 A wide variety of tissues from a number of different species contains varying amounts of DMO-like interfering material. The specific chemical composition of these substances is not known. However, this material is clearly not related to the presence of barbiturates, since such substances are found in the absence of barbiturate administration. Typical concentrations of this material, expressed in milligrams DMO per liter cell $\mathrm{H}_{2} \mathrm{O}$, are as follows: human, dog, and Elasmobranch erythrocyte, $20 \mathrm{mg}$ per L; dog and human skeletal muscle, $20 \mathrm{mg}$ per L; Elasmobranch skeletal muscle, 30 $\mathrm{mg}$ per L; Elasmobranch brain, $50 \mathrm{mg}$ per L; dog brain, $65 \mathrm{mg}$ per $\mathrm{L}$; rat liver mitochondria, $100 \mathrm{mg}$ per $\mathrm{L}$.

This interfering substance(s) appears to be unaffected by $\mathrm{pH}$ changes since its concentration remained essentially constant in dog brain and muscle and dogfish erythrocyte, muscle, and brain when extracellular $\mathrm{pH}$ was modified by $\mathrm{CO}_{2}$ inhalation, by $\mathrm{NaHCO}_{3}$ administration, and $\mathrm{HCl}$ administration. Its concentration in brain water also remained essentially constant with the passage of time (up to 8 hours) in the unmanipulated dog. Because of this constancy, the use of a single blank for each dog was considered acceptable.

3 Buchler Instruments, Laboratory Glass and Instruments Corp., New York, N. Y. 
Cotlove, Trantham, and Bowman (9). For sulfate space determinations, weighed samples of plasma and brain homogenate were dried, and total radioactivity was measured in a gas flow beta scintillation counter.4

Chloride concentration and radioactivity were expressed in microequivalents or number of counts, respectively, per gram of brain water or plasma water. The water content of each brain sample was experimentally determined as described above. In calculation of chloride concentrations and counts per volume of plasma water, plasma was assumed to consist of $93 \%$ water. It was also assumed that the distribution of both the chloride and sulfate ions between plasma and extracellular fluid obeyed the Gibbs-Donnan equilibrium, and accordingly, plasma values were multiplied by a factor of 1.05 and 1.10 , respectively, to obtain corresponding values for ECF. Both ions were further assumed to be entirely extracellular so that the chloride and sulfate spaces of brain were equal to the concentration of chloride and radioactive counts in brain water divided by the concentration of chloride and radioactive counts in ECF. For example:

$$
\text { sulfate space }=\frac{\frac{\text { no. counts } / g \text { brain }}{\% \text { brain water }}}{\frac{\text { no. counts } / \mathrm{ml} \text { plasma }}{0.93} \times 1.10} \times 100 .
$$

Note that these estimates of brain ECF are expressed as a percentage of total brain water rather than in the more customary fashion as a percentage of total brain weight. This mode of expression was chosen because this measurement was to be used in subsequent calculations as a correction factor for the "contamination" of a given sample of tissue with ECF.

Calculation of intracellular $p H$. The theoretical considerations and mathematical manipulations used to derive the following formula for intracellular $\mathrm{pH},(\mathrm{pH})_{4}$, by the DMO technique are adequately discussed elsewhere $(2,5)$.

$$
(\mathrm{pH})_{i}=p K^{\prime} a+\log \frac{(\text { total DMO })_{i}\left(10^{\mathrm{pH}_{e}}-p K^{\prime} a+1\right)}{-(\text { total DMO })_{e}} .
$$

The value of $p K^{\prime} a$ given by Waddell and Butler for $\mathrm{DMO}$ is 6.13 at $37^{\circ} \mathrm{C}$. The calculated $\mathrm{DMO}^{-}$concentration of plasma water was multiplied by 1.05 to correct for Gibbs-Donnan equilibrium effect on the distribution of $\mathrm{DMO}^{-}$ions between plasma and extracellular fluid. Extracellular $\mathrm{pH}\left(\mathrm{pH}_{0}\right)$ was derived by the addition of $0.02 \mathrm{U}$ to plasma $\mathrm{pH}$. The total DMO concentration of intracellular brain water (total DMO), was calculated from the following formula:

$\frac{(t \text { tal DMO })_{\text {brain } \mathrm{H}_{2} \mathrm{O}-\% \text { brain } \mathrm{H}_{2} \mathrm{O}_{\mathrm{ECF}} \times(\text { total DMO) }}}{\% \text { brain } \mathrm{H}_{2} \mathrm{O}_{i}}$,

where \% brain $\mathrm{H}_{2} \mathrm{O}_{\text {ECF }}$ and $\%$ brain $\mathrm{H}_{2} \mathrm{O}_{i}$ refer to the percentage of total brain water represented by extracellular and intracellular fluid, respectively. No correction was made for the presence of cerebrospinal fluid

4 Model 186, Nuclear-Chicago, Des Plaines, Ill.
(CSF) in brain homogenate. Gross contamination by this fluid was prevented by the technique of preparation. A small amount of CSF penetrating the deep recesses of the brain was undoubtedly present. This fluid would have a DMO concentration somewhere between the concentration in plasma and the concentration in brain intracellular water and presumably should lead to no substantial inaccuracy in the calculated intracellular $\mathrm{pH}$ of brain. Two values for $\mathrm{pH}_{\text {، }}$ were calculated, one based on the chloride space as an estimate of brain ECF, $\mathrm{pH}_{4} \mathrm{Cl}$, and one based on the sulfate space, $\mathrm{pH}_{4} \mathrm{SO}_{4}$. In those instances in which a sulfate space was not determined experimentally, the values for sulfate space obtained in the control group of glucose dogs was used, i.e., $5 \%$ at 4 hours and $7 \%$ at 5 hours.

Bicarbonate concentration in millimoles per liter of plasma was calculated from the mass action law : $\mathrm{HCO}_{3}{ }^{-}=$ antilog $(\mathrm{pH}-6.10) \times 0.0301 \times \mathrm{PCO}_{2}$.

\section{Results}

Rate of equilibration of DMO in brain water. These data are shown in Table I. They show that after iv injection of $\mathrm{DMO}$, the rate of equilibration of DMO with brain water does not appear to be substantially slower in brain water than in muscle water. By the end of 30 minutes, total DMO concentration in brain water achieved 84 to $92 \%$ of its equilibrium value, and by 60 to 120 minutes equilibrium appeared to be complete. Thus the penetration of this substance does not appear to be influenced by the "blood-brain barrier," and the preliminary period of 4 hours used for equilibration appears to be sufficiently long for this purpose.

Rate of achievement of steady state radiosulfate in brain. Figure 1 summarizes the data con-

TABLE I

\begin{tabular}{|c|c|c|c|c|}
\hline Dog no. & Time & $\begin{array}{c}\text { Plasma } \\
\text { DMO }\end{array}$ & $\begin{array}{l}\text { Brain } \\
\text { DMO }\end{array}$ & $\begin{array}{l}\text { Muscle } \\
\text { DMO }\end{array}$ \\
\hline & hours & $m g / L H_{2} O$ & $m g / L H_{2} \mathrm{O}$ & $\mathrm{mg} / \mathrm{L} \mathrm{H}_{2} \mathrm{O}$ \\
\hline 1 & $\begin{array}{l}0.5 \\
1.75\end{array}$ & $\begin{array}{l}422 \\
398\end{array}$ & $\begin{array}{l}205 \\
22.3\end{array}$ & $\begin{array}{l}253 \\
247\end{array}$ \\
\hline 2 & $\begin{array}{l}0.5 \\
1.0\end{array}$ & $\begin{array}{l}497 \\
510\end{array}$ & $\begin{array}{l}323 \\
391\end{array}$ & $\begin{array}{l}317 \\
345\end{array}$ \\
\hline 3 & $\begin{array}{l}1.0 \\
3.0\end{array}$ & $\begin{array}{l}760 \\
676\end{array}$ & $\begin{array}{l}227 \\
219\end{array}$ & $\begin{array}{l}230 \\
204\end{array}$ \\
\hline 4 & $\begin{array}{l}1 \\
2\end{array}$ & $\begin{array}{l}250 \\
244\end{array}$ & $\begin{array}{l}140 \\
137\end{array}$ & $\begin{array}{l}136 \\
146\end{array}$ \\
\hline
\end{tabular}

Rate of equilibration of DMO* in brain water as compared with muscle water

${ }^{*}$ DMO $=$ 5,5-dimethyl-2,4-oxazolidinedione. 


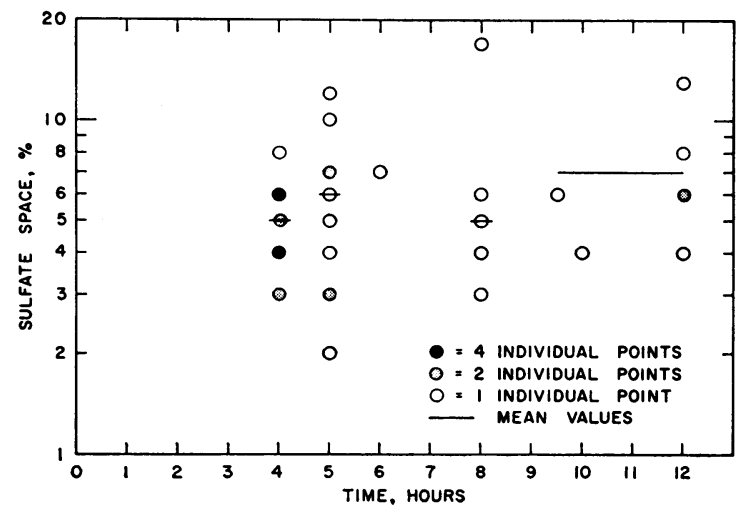

Fig. 1. Sulfate space in the brain as a Function of TIME AFTER IV INJECTION OF $\mathrm{S}^{35} \mathrm{O}_{4}$.

cerning sulfate space in the 11 dogs specifically studied for this purpose and in the 5 dogs in which sulfate space was determined together with control measurements of intracellular $\mathrm{pH}$ during glucose infusion. The data have been plotted on semilogarithmic paper with time on the abscissa plotted arithmetically and sulfate space on the ordinate plotted logarithmically. These data appear to justify the conclusion that a steady state with respect to sulfate penetration of brain has occurred within 4 to 5 hours. The mean sulfate space at 4 hours averaged $5 \%$; at 5 hours, $6 \%$; at 8 hours, $7 \%$; and at 9 to 12 hours, $7 \%$. Com- parison of the 4-and 5-hour sulfate spaces by the $t$ test revealed no significant difference between these values.

Control observations. The mean control data for all $28 \mathrm{dogs}$ are given in Table II. From the time of the first blood and brain samples ( 0 hour) to the end of the fourth hour, all the dogs were maintained in a reasonably steady metabolic state. Mean plasma $\mathrm{pH}$ fell $0.03 \mathrm{U}, \mathrm{PCO}_{2}$ was essentially unchanged, and plasma bicarbonate concentration dropped 1.3 mmoles per L. The total water content and chloride space of the brain did not change significantly.

At 4 hours the values for mean plasma $\mathrm{pH}$ and $\mathrm{PCO}_{2}$ were $7.39 \pm 0.08 \mathrm{U}$ and $22 \pm 6 \mathrm{~mm} \mathrm{Hg}$, respectively. The latter figure indicates that the dogs were hyperventilated during the procedure. The mean chloride space of $39 \pm 3 \%$ of total brain water ( $30 \%$ brain weight) is in close agreement with the value of $31 \%$ brain weight reported by Davson (10). Mean intracellular $\mathrm{pH}$, based on the chloride space as an estimate of brain ECF, $\mathrm{pH}_{\mathrm{i}} \mathrm{Cl}$, was $6.69 \pm 0.19 \mathrm{U}$; the sulfate space derived intracellular $\mathrm{pH}, \mathrm{pH}_{\mathrm{i}} \mathrm{SO}_{4}$, was $7.08 \pm 0.08$ U. Thus, based on $\mathrm{pH}_{\mathrm{i}} \mathrm{Cl}$, brain intracellular fluid was found to be $0.70 \mathrm{pH} \mathrm{U}$ more acidic than plasma and, based on $\mathrm{pH}_{\mathrm{i}} \mathrm{SO}_{4}, 0.31 \mathrm{pH} \mathrm{U}$ more acidic. Even assuming a brain ECF of $0 \%$,

TABLE II

Mean control data

\begin{tabular}{|c|c|c|c|c|c|c|}
\hline \multirow[b]{2}{*}{ Time } & & \multicolumn{5}{|c|}{ Plasma } \\
\hline & & $\mathrm{pH}$ & Pcon & $\mathrm{HCO}_{3}-$ & & \\
\hline hours & & $U$ & $m m \mathrm{Hg}$ & mumoles $/ L$ & & \\
\hline 0 & & $\begin{array}{c}7.42 \\
\pm 0.06^{*}\end{array}$ & $\begin{array}{r}23 \\
\pm 6\end{array}$ & $\begin{array}{r}14.1 \\
\pm 2.4\end{array}$ & & \\
\hline \multirow[t]{2}{*}{4} & & $\begin{array}{r}7.39 \\
\pm 0.08\end{array}$ & $\begin{array}{r}22 \\
\pm 6\end{array}$ & $\begin{array}{r}12.8 \\
\pm 2.6\end{array}$ & & \\
\hline & \multicolumn{6}{|c|}{ Brain } \\
\hline Time & Total $\mathrm{H}_{2} \mathrm{O}$ & Chloride space & Sulfate space & $\mathrm{pH}_{\mathrm{i}} \mathrm{Cl} \dagger$ & $\mathrm{pH}_{\mathrm{i}} \mathrm{SO}_{4}$ & DMO \\
\hline hours & $\%$ & $\begin{array}{c}\% \text { total brain } \\
\mathrm{H}_{2} \mathrm{O}\end{array}$ & $\begin{array}{c}\% \text { total brain } \\
\mathrm{H}_{2} \mathrm{O}\end{array}$ & $U$ & $U$ & $\begin{array}{l}m g / L \text { total } \\
\text { brain } \mathrm{H}=\mathrm{O}\end{array}$ \\
\hline 0 & $\begin{array}{r}76 \\
\pm 2\end{array}$ & $\begin{array}{r}39 \\
\pm 3\end{array}$ & & & & \\
\hline 4 & $\begin{array}{r}77 \\
\pm 1\end{array}$ & $\begin{array}{r}39 \\
\pm 3\end{array}$ & $\begin{array}{r}5 \ddagger \\
\pm 2\end{array}$ & $\begin{array}{c}6.69 \S \\
\pm 0.19\end{array}$ & $\begin{array}{r}7.08 \\
\pm 0.08\end{array}$ & $\begin{array}{r}198 \\
\pm 37\end{array}$ \\
\hline
\end{tabular}

* Standard deviations.

$+\mathrm{pH}_{\mathrm{i}}=$ intracellular $\mathrm{pH} ;-\mathrm{Cl}$, based on the chloride space as an estimate of brain extracellular fluid; $-\mathrm{SO}_{4}$, based on the sulfate space.

$\ddagger 10$ dogs only.

$\$$ Negative values for intracellular DMO obtained in 4 dogs. 
there is still a substantial hydrogen ion gradient between extracellular and brain water. Mean plasma bicarbonate concentration was $12.8 \pm 2.6$ mmoles per $\mathrm{L}$. The DMO concentration was 374 $\pm 70 \mathrm{mg}$ per $\mathrm{L}$ of plasma water and $198 \pm 37$ $\mathrm{mg}$ per $\mathrm{L}$ of total brain water.

In addition to the mean control data given in Table II, the data for each individual dog at the 4-hour control period are included in Table III. Note that in 4 dogs $\mathrm{pH}_{\mathrm{i}} \mathrm{Cl}$ could not be calculated, since a negative value for brain intracellular DMO concentration was obtained when the chloride space was used as an estimate of brain ECF.

Experimental modification of $p H$. Individual dog data are given in Table III, and the mean data for each of the 5 experimental groups of animals are shown in Table IV. The data at 5 hours are expressed as the differences between the values at the fifth hour and the values at the fourth hour, i.e., 5 hour -4 hour.

Control dogs. The results obtained in the 7 dogs that received $200 \mathrm{ml}$ of $5 \%$ glucose in water served as control data for the other 4 experimental groups of dogs. There was a small but significant $(\mathrm{p}<0.01)$ drop in both plasma and brain $\mathrm{pH}$ in this group. Plasma $\mathrm{pH}$ fell $0.07 \pm 0.05 \mathrm{U}, \mathrm{pH}_{\mathrm{i}} \mathrm{Cl}$ fell $0.18 \pm 0.16 \mathrm{U}$, and $\mathrm{pH}_{\mathrm{i}} \mathrm{SO}_{4}$ dropped $0.10 \pm 0.07 \mathrm{U}$. No significant change occurred in $\mathrm{PCO}_{2}$, but bicarbonate concentration dropped $1.1 \pm 1.9$ mmoles per $\mathrm{L}$ in plasma water. These changes were probably the result of metabolic acidosis, presumably related to barbiturate administration and the trauma associated with the study. No change occurred in the percentage of total brain water, and the chloride and sulfate spaces of the brain increased only $1 \pm 2 \%$ and $2 \pm 3 \%$, respectively, indicating that the trauma incident to biopsy of the brain did not cause significant edema at the sites chosen for subsequent sampling.

Bicarbonate dogs. The administration of 150 mmoles of $\mathrm{NaHCO}_{3}$ to 6 dogs resulted in a mean rise in plasma $\mathrm{pH}$ of $0.31 \pm 0.07 \mathrm{U}$ at 1 hour. Mean brain $\mathrm{pH}_{\mathrm{i}} \mathrm{SO}_{4}$, on the other hand, rose only $0.10 \pm 0.08 \mathrm{U}$. Mean plasma $\mathrm{Pco}_{2}$ increased $6 \pm 1 \mathrm{~mm} \mathrm{Hg}$ as a result of buffering of bicarbonate at a relatively fixed minute volume of ventilation (11). Intracellular $\mathrm{PCO}_{2}$ could be expected to increase to the same extent and would tend to make intracellular $\mathrm{pH}$ more acidic, thus accounting in part for the small magnitude of the rise in $\mathrm{pH}_{\mathrm{i}}$.

The increase in calculated hydrogen ion gradient between brain and plasma occurred as the result of a shift of DMO out of brain intracellular water. Thus, mean plasma DMO concentration rose $22 \pm 12 \mathrm{mg}$ per $\mathrm{L}$, and mean brain DMO concentration fell $45 \pm 25 \mathrm{mg}$ per $\mathrm{L}$. The rise in plasma total DMO is even more impressive considering that the effect of the infusion is to lower this figure. Cells other than brain cells contribute to this rise, however, since the slow equilibration of the bicarbonate ion across the cell membranes of other tissues is well recognized.

A value for $\mathrm{pH}_{\mathrm{i}} \mathrm{Cl}$ could not be calculated in any of the dogs after bicarbonate infusion. With the drop in total DMO concentration in brain water occurring after bicarbonate injection, correction for extracellular "contamination" of total brain DMO based on the chloride space led to a negative value for intracellular DMO, a result encountered in a number of other instances when the chloride space was used as an estimate of brain ECF. This observation is entirely independent of any assumption concerning steadystate conditions or achievement of equilibrium and operationally depends only on simultaneous measurements of plasma and brain DMO concentrations and plasma and brain chloride concentrations. Although a mean rise of $6 \pm 3 \%$ occurred in the chloride space, this increase by itself does not account for these results. They are due almost entirely to the drop in total brain DMO concentration.

Tris dogs. When $150 \mathrm{mEq}$ of Tris was administered to 4 dogs, mean plasma $\mathrm{pH}$ rose 0.21 $\pm 0.06 \mathrm{U}$, whereas mean $\mathrm{pH}_{\mathrm{i}} \mathrm{SO}_{4}$ fell $0.02 \pm 0.17$ $\mathrm{U}$. As was the case after bicarbonate administration, this increase in calculated hydrogen ion gradient between brain water and plasma occurred as a result of the fall in DMO concentration in total brain water, amounting to $78 \pm 25$ mg per L. In contrast to the results obtained with bicarbonate, however, plasma DMO concentration fell $24 \pm 26 \mathrm{mg}$ per L. This difference in the effect of Tris and bicarbonate on plasma DMO concentration may be explained by the difference in the effect of these two substances on the intracellular $\mathrm{pH}$ of tissues other 
TABLE

Summary of changes in extracellular and intracellular

\begin{tabular}{|c|c|c|c|c|c|c|c|c|c|}
\hline & & \multicolumn{8}{|c|}{ Plasma } \\
\hline \multirow[b]{2}{*}{ Dog no. } & & \multicolumn{2}{|c|}{$\mathrm{pH}$} & \multicolumn{2}{|c|}{ Pco2 } & \multicolumn{2}{|c|}{$\mathrm{HCO}_{3}^{-}$} & \multicolumn{2}{|c|}{ DMO } \\
\hline & & 4 hours & $5-4$ hours* & 4 hours & $5-4$ hours & 4 hours & $5-4$ hours & 4 hours & $5-4$ hours \\
\hline & & \multicolumn{2}{|c|}{$U^{v}$} & \multicolumn{2}{|c|}{$m m \mathrm{Hg}$} & \multicolumn{2}{|c|}{ mmoles $/ L$} & \multicolumn{2}{|c|}{ mmoles $/ L$} \\
\hline \multirow[t]{2}{*}{$\begin{array}{l}5 \% \text { glucose in } \\
\mathrm{H}_{2} \mathrm{O}\end{array}$} & $\begin{array}{l}1 \\
2 \\
3 \\
4 \\
5 \\
6 \\
7\end{array}$ & $\begin{array}{l}7.37 \\
7.37 \\
7.36 \\
7.31 \\
7.45 \\
7.49 \\
7.33 \\
\end{array}$ & $\begin{array}{l}-0.04 \\
-0.11 \\
-0.03 \\
-0.18 \\
-0.04 \\
-0.04 \\
-0.03\end{array}$ & $\begin{array}{l}15 \\
26 \\
27 \\
23 \\
15 \\
13 \\
29\end{array}$ & $\begin{array}{r}+1 \\
+12 \\
0 \\
-2 \\
-2 \\
+1 \\
-1\end{array}$ & $\begin{array}{r}8.4 \\
14.6 \\
14.8 \\
11.2 \\
10.1 \\
9.6 \\
14.8\end{array}$ & $\begin{array}{l}-0.3 \\
+1.9 \\
-1.0 \\
-4.4 \\
-2.1 \\
-0.2 \\
-1.4\end{array}$ & $\begin{array}{l}317 \\
317 \\
288 \\
336 \\
426 \\
430 \\
427\end{array}$ & $\begin{array}{l}-4 \\
-12 \\
-27 \\
-64 \\
-32 \\
-49 \\
-58\end{array}$ \\
\hline & & $\begin{array}{r}7.38 \\
\pm 0.07\end{array}$ & $\begin{array}{l}-0.07 \\
\pm 0.05\end{array}$ & $\begin{array}{r}23 \\
\pm 7\end{array}$ & $\begin{array}{l}+1 \\
\pm 5\end{array}$ & $\begin{array}{r}12.6 \\
\pm 2.7\end{array}$ & $\begin{array}{l}-1.1 \\
\pm 1.9\end{array}$ & $\begin{array}{r}363 \\
\pm 62\end{array}$ & $\begin{array}{l}-35 \\
\pm 23\end{array}$ \\
\hline \multirow[t]{2}{*}{$\mathrm{NaHCO}_{3}$} & $\begin{array}{r}8 \\
9 \\
10 \\
11 \\
12 \\
13\end{array}$ & $\begin{array}{l}7.37 \\
7.43 \\
7.54 \\
7.39 \\
7.34 \\
7.38 \\
\end{array}$ & $\begin{array}{l}+0.33 \\
+0.38 \\
+0.27 \\
+0.21 \\
+0.39 \\
+0.31 \\
\end{array}$ & $\begin{array}{l}22 \\
21 \\
15 \\
24 \\
23 \\
23 \\
\end{array}$ & $\begin{array}{l}+6 \\
+5 \\
+5 \\
+8 \\
+5 \\
+6 \\
\end{array}$ & $\begin{array}{l}12.3 \\
13.5 \\
12.4 \\
14.1 \\
12.0 \\
13.8 \\
\end{array}$ & $\begin{array}{l}+21.2 \\
+26.6 \\
+18.5 \\
+16.4 \\
+24.0 \\
+21.3 \\
\end{array}$ & $\begin{array}{l}274 \\
396 \\
362 \\
314 \\
345 \\
305 \\
\end{array}$ & $\begin{array}{r}+8 \\
+36 \\
+12 \\
+17 \\
+38 \\
+24 \\
\end{array}$ \\
\hline & & $\begin{array}{r}7.40 \\
\pm 0.06\end{array}$ & $\begin{array}{l}+0.31 \\
\pm 0.07\end{array}$ & $\begin{array}{r}21 \\
\pm 3\end{array}$ & $\begin{array}{l}+6 \\
\pm 1\end{array}$ & $\begin{array}{r}13.0 \\
\pm 0.9\end{array}$ & $\begin{array}{r}+21.3 \\
\pm 3.6\end{array}$ & $\begin{array}{r}333 \\
\pm 44\end{array}$ & $\begin{array}{l}+22 \\
\pm 12\end{array}$ \\
\hline \multirow[t]{2}{*}{ Tris } & $\begin{array}{l}14 \\
15 \\
16 \\
17\end{array}$ & $\begin{array}{l}7.39 \\
7.50 \\
7.34 \\
7.47\end{array}$ & $\begin{array}{r}+0.14 \\
+0.20 \\
+0.29 \\
+0.21\end{array}$ & $\begin{array}{l}34 \\
22 \\
20 \\
22\end{array}$ & $\begin{array}{r}0 \\
+4 \\
-4 \\
+4\end{array}$ & $\begin{array}{l}20.0 \\
16.6 \\
10.5 \\
15.5\end{array}$ & $\begin{array}{r}+7.5 \\
+14.6 \\
+5.8 \\
+14.2\end{array}$ & $\begin{array}{l}350 \\
502 \\
366 \\
361\end{array}$ & $\begin{array}{r}00 \\
-24 \\
-60 \\
-12\end{array}$ \\
\hline & & $\begin{array}{r}7.42 \\
\pm 0.07\end{array}$ & $\begin{array}{l}+0.21 \\
\pm 0.06\end{array}$ & $\begin{array}{r}24 \\
\pm 2\end{array}$ & $\begin{array}{l}+1 \\
\pm 4\end{array}$ & $\begin{array}{r}15.6 \\
\pm 3.9\end{array}$ & $\begin{array}{r}+10.5 \\
\pm 4.8\end{array}$ & $\begin{array}{r}395 \\
\pm 71\end{array}$ & $\begin{array}{l}-24 \\
\pm 26\end{array}$ \\
\hline \multirow[t]{2}{*}{$\mathrm{HCl}$} & $\begin{array}{l}18 \\
19 \\
20 \\
21 \\
22 \\
23\end{array}$ & $\begin{array}{l}7.28 \\
7.35 \\
7.19 \\
7.25 \\
7.42 \\
7.49\end{array}$ & $\begin{array}{l}-0.42 \\
-0.14 \\
-0.35 \\
-0.28 \\
-0.16 \\
-0.27\end{array}$ & $\begin{array}{l}19 \\
28 \\
28 \\
32 \\
20 \\
12\end{array}$ & $\begin{array}{l}-3 \\
-4 \\
-6 \\
+6 \\
-2 \\
-1\end{array}$ & $\begin{array}{r}8.7 \\
15.0 \\
10.4 \\
13.6 \\
12.6 \\
8.9\end{array}$ & $\begin{array}{l}-5.9 \\
-5.7 \\
-6.8 \\
-5.1 \\
-4.8 \\
-4.5\end{array}$ & $\begin{array}{l}371 \\
382 \\
290 \\
360 \\
401 \\
583\end{array}$ & $\begin{array}{r}-147 \\
-49 \\
-101 \\
-80 \\
-88 \\
-165\end{array}$ \\
\hline & & $\begin{array}{r}7.33 \\
\pm 0.11\end{array}$ & $\begin{array}{l}-0.27 \\
\pm 0.11\end{array}$ & $\begin{array}{r}23 \\
\pm 7\end{array}$ & $\begin{array}{l}-1 \\
\pm 4\end{array}$ & $\begin{array}{r}11.5 \\
\pm 2.6\end{array}$ & $\begin{array}{l}-5.5 \\
\pm 0.8\end{array}$ & $\begin{array}{r}381 \\
\pm 109\end{array}$ & $\begin{array}{r}-105 \\
\pm 43\end{array}$ \\
\hline \multirow[t]{2}{*}{$\mathrm{CO}_{2}$} & $\begin{array}{l}24 \\
25 \\
26 \\
27 \\
28\end{array}$ & $\begin{array}{l}7.41 \\
7.35 \\
7.54 \\
7.47 \\
7.53\end{array}$ & $\begin{array}{l}-0.45 \\
-0.40 \\
-0.64 \\
-0.52 \\
-0.58\end{array}$ & $\begin{array}{l}26 \\
23 \\
15 \\
17 \\
17\end{array}$ & $\begin{array}{l}+58 \\
+46 \\
+76 \\
+57 \\
+61\end{array}$ & $\begin{array}{l}16.0 \\
12.3 \\
12.4 \\
12.0 \\
13.8\end{array}$ & $\begin{array}{l}+2.3 \\
+2.4 \\
+4.1 \\
+3.8 \\
+2.8\end{array}$ & $\begin{array}{l}391 \\
444 \\
461 \\
374 \\
400 \\
\end{array}$ & $\begin{array}{r}-52 \\
-69 \\
-104 \\
-102 \\
-103 \\
\end{array}$ \\
\hline & & $\begin{array}{r}\overline{7.46} \\
\pm 0.09\end{array}$ & $\begin{array}{l}-0.52 \\
\pm 0.30\end{array}$ & $\begin{array}{r}\overline{20} \\
\pm 5\end{array}$ & $\begin{array}{l}+60 \\
\pm 11\end{array}$ & $\begin{array}{r}13.3 \\
\pm 1.6\end{array}$ & $\begin{array}{l}+3.1 \\
\pm 0.8\end{array}$ & $\begin{array}{r}414 \\
\pm 36\end{array}$ & $\begin{array}{l}-86 \\
\pm 24\end{array}$ \\
\hline Mean & & $\begin{array}{r}7.39 \\
\pm 0.08\end{array}$ & & $\begin{array}{r}22 \\
\pm 6\end{array}$ & & $\begin{array}{r}12.8 \\
\pm 2.6\end{array}$ & & $\begin{array}{r}374 \\
\pm 70\end{array}$ & \\
\hline
\end{tabular}

* Data at 5 hours expressed as values at the fifth hour minus values at the fourth hour.

than brain. Robin, Wilson, and Bromberg (2) have shown that, whereas bicarbonate causes relatively little change in whole body $\mathrm{pH}_{\mathrm{i}}$, Tris causes a greater rise in whole body $\mathrm{pH}_{1}$ than in plasma $\mathrm{pH}$. The over-all effect of Tris, therefore, is to lower plasma DMO rather than to increase it. These observations, together with the present ones, suggest that Tris crosses most cell membranes with ease but has difficulty entering brain cells. Further evidence for this view comes from the work of Nahas (12), who found that after 6 hours the concentration of $\mathrm{C}^{14}$-labeled Tris in CSF was only 7 to $15 \%$ of the plasma concentration, with the distribution between 
III

parameters after modification of extracellular $p H$

\begin{tabular}{|c|c|c|c|c|c|c|c|c|c|}
\hline \multicolumn{10}{|c|}{ Brain } \\
\hline \multicolumn{2}{|c|}{ Total $\mathrm{H}_{2} \mathrm{O}$} & \multicolumn{2}{|c|}{ Chloride space } & \multicolumn{2}{|c|}{$\mathrm{pH}_{\mathrm{i}} \mathrm{Cl}$} & \multicolumn{2}{|c|}{$\mathrm{pH}_{\mathrm{i}} \mathrm{SO}_{4}$} & \multicolumn{2}{|c|}{ DMO } \\
\hline 4 hours & $5-4$ hours & 4 hours & $5-4$ hours & 4 hours & $5-4$ hours & 4 hours & $5-4$ hours & 4 hours & $5-4$ hours \\
\hline \multicolumn{2}{|r|}{$\%$} & \multicolumn{2}{|c|}{$\%$ brain $\mathrm{H}_{2} \mathrm{O}$} & \multicolumn{2}{|c|}{$U$} & \multicolumn{2}{|c|}{$U$} & \multicolumn{2}{|c|}{ mmoles $/ L$ total brain $\mathrm{H}_{2} \mathrm{O}$} \\
\hline $\begin{array}{l}73 \\
77 \\
77 \\
80 \\
78 \\
77 \\
77\end{array}$ & $\begin{array}{r}+2 \\
+2 \\
+1 \\
+1 \\
-1 \\
-1 \\
-1\end{array}$ & $\begin{array}{l}37 \\
42 \\
38 \\
36 \\
34 \\
41 \\
41\end{array}$ & $\begin{array}{r}+2 \\
-4 \\
+3 \\
+3 \\
+1 \\
+3 \\
0\end{array}$ & $\begin{array}{l}7.03 \\
6.87 \\
6.52 \\
6.89 \\
6.88 \\
6.42 \\
6.71\end{array}$ & $\begin{array}{r}-0.22 \\
-0.23 \\
-0.20 \\
-0.44 \\
-0.18 \\
-0.05 \\
-0.09 \\
\end{array}$ & $\begin{array}{l}7.18 \\
7.13 \\
7.00 \\
7.08 \\
7.15 \\
7.12 \\
7.05\end{array}$ & $\begin{array}{l}-0.11 \\
-0.17 \\
-0.07 \\
-0.24 \\
-0.09 \\
-0.04 \\
-0.01\end{array}$ & $\begin{array}{l}216 \dagger \\
197 \\
143 \\
212 \\
231 \\
208 \\
244 \\
\end{array}$ & $\begin{array}{l}-28 \\
-26 \\
-13 \\
-59 \\
-33 \\
-14 \\
-28\end{array}$ \\
\hline $\begin{array}{r}77 \\
\pm 2\end{array}$ & $\begin{array}{r}0 \\
\pm 1\end{array}$ & $\begin{array}{l}\overline{38} \\
\pm 3\end{array}$ & $\begin{array}{l}+1 \\
\pm 2\end{array}$ & $\begin{array}{r}6.76 \\
\pm 0.23\end{array}$ & $\begin{array}{l}-0.18 \\
\pm 0.16\end{array}$ & $\begin{array}{r}7.10 \\
\pm 0.07\end{array}$ & $\begin{array}{l}-0.10 \\
\pm 0.07\end{array}$ & $\begin{array}{r}207 \\
\pm 32\end{array}$ & $\begin{array}{l}-29 \\
\pm 15\end{array}$ \\
\hline $\begin{array}{l}76 \\
76 \\
79 \\
77 \\
77 \\
78\end{array}$ & $\begin{array}{l}+1 \\
-7 \\
-4 \\
-1 \\
-6 \\
-1\end{array}$ & $\begin{array}{l}37 \\
43 \\
35 \\
30 \\
38 \\
43 \\
\end{array}$ & $\begin{array}{r}+3 \\
+3 \\
+5 \\
+11 \\
+9 \\
+3 \\
\end{array}$ & $\begin{array}{c}6.24 \\
6.60 \\
M \ddagger \\
6.60 \\
6.89 \\
6.82 \\
\end{array}$ & $\begin{array}{l}\mathbf{M} \\
\mathbf{M} \\
\mathbf{M} \\
\mathbf{M} \\
\mathbf{M} \\
\mathbf{M}\end{array}$ & $\begin{array}{l}6.96 \\
7.14 \\
7.06 \\
6.97 \\
7.10 \\
7.14 \\
\end{array}$ & $\begin{array}{r}+0.12 \\
+0.02 \\
0.00 \\
+0.15 \\
+0.23 \\
+0.07 \\
\end{array}$ & $\begin{array}{l}124 \\
211 \\
140 \\
139 \\
214 \\
187 \\
\end{array}$ & $\begin{array}{r}-37 \\
-85 \\
-46 \\
-8 \\
-39 \\
-58 \\
\end{array}$ \\
\hline $\begin{array}{r}77 \\
\pm 1\end{array}$ & $\begin{array}{l}-3 \\
\pm 3\end{array}$ & $\begin{array}{r}38 \\
\pm 4\end{array}$ & $\begin{array}{l}+6 \\
\pm 3\end{array}$ & $\begin{array}{r}6.63 \\
\pm 0.25\end{array}$ & $\mathbf{M}$ & $\begin{array}{r}7.06 \\
\pm 0.09\end{array}$ & $\begin{array}{l}+0.10 \\
\pm 0.08\end{array}$ & $\begin{array}{r}169 \\
\pm 40\end{array}$ & $\begin{array}{l}-45 \\
\pm 25\end{array}$ \\
\hline $\begin{array}{l}78 \\
78 \\
67 \\
80 \\
\end{array}$ & $\begin{array}{r}0 \\
-1 \\
-2 \\
-1 \\
\end{array}$ & $\begin{array}{l}40 \\
39 \\
39 \\
43\end{array}$ & $\begin{array}{r}+2 \\
+4 \\
+19 \\
+1\end{array}$ & $\begin{array}{l}6.64 \\
6.59 \\
6.81 \\
6.56 \\
\end{array}$ & $\begin{array}{l}\mathbf{M} \\
\mathbf{M} \\
\mathbf{M} \\
\mathbf{M}\end{array}$ & $\begin{array}{l}7.07 \\
7.14 \\
7.08 \\
7.15\end{array}$ & $\begin{array}{l}-0.06 \\
-0.12 \\
+0.23 \\
-0.15\end{array}$ & $\begin{array}{l}186 \\
245 \\
216 \\
188 \\
\end{array}$ & $\begin{array}{r}-55 \\
-109 \\
-59 \\
-88\end{array}$ \\
\hline $\begin{array}{r}78 \\
\pm 1\end{array}$ & $\begin{array}{l}-1 \\
\pm 1\end{array}$ & $\begin{array}{r}40 \\
\pm 1\end{array}$ & $\begin{array}{l}+6 \\
\pm 7\end{array}$ & $\begin{array}{r}6.65 \\
\pm 0.11\end{array}$ & $\mathbf{M}$ & $\begin{array}{r}7.11 \\
\pm 0.04\end{array}$ & $\begin{array}{l}-0.02 \\
\pm 0.17\end{array}$ & $\begin{array}{r}209 \\
\pm 28\end{array}$ & $\begin{array}{l}-78 \\
\pm 25\end{array}$ \\
\hline $\begin{array}{l}76 \\
76 \\
79 \\
78 \\
78 \\
79\end{array}$ & $\begin{array}{r}+1 \\
-4 \\
-1 \\
-6 \\
+1 \\
0\end{array}$ & $\begin{array}{l}42 \\
35 \\
43 \\
36 \\
40 \\
36\end{array}$ & $\begin{array}{r}0 \\
-3 \\
-2 \\
+4 \\
-4 \\
+1\end{array}$ & $\begin{array}{l}6.90 \\
6.73 \\
6.40 \\
6.77 \\
6.69 \\
M\end{array}$ & $\begin{array}{c}+0.24 \\
+0.16 \\
+0.51 \\
+0.21 \\
+0.35 \\
M\end{array}$ & $\begin{array}{l}7.10 \\
7.04 \\
6.89 \\
6.99 \\
7.09 \\
7.01\end{array}$ & $\begin{array}{l}-0.05 \\
-0.04 \\
-0.01 \\
+0.01 \\
+0.03 \\
-0.01\end{array}$ & $\begin{array}{l}255 \\
151 \\
163 \\
217 \\
215 \\
227\end{array}$ & $\begin{array}{l}+71 \\
+5 \\
+40 \\
+35 \\
+24 \\
+45\end{array}$ \\
\hline $\begin{array}{r}\overline{78} \\
\pm 1\end{array}$ & $\begin{array}{l}-2 \\
\pm 3\end{array}$ & $\begin{array}{r}\overline{38} \\
\pm 3\end{array}$ & $\begin{array}{l}-1 \\
\pm 3\end{array}$ & $\begin{array}{r}6.70 \\
\pm 0.18\end{array}$ & $\begin{array}{l}+0.29 \\
\pm 0.14\end{array}$ & $\begin{array}{r}7.02 \\
\pm 0.08\end{array}$ & $\begin{array}{l}-0.01 \\
\pm 0.03\end{array}$ & $\begin{array}{r}205 \\
\pm 40\end{array}$ & $\begin{array}{l}+37 \\
\pm 22\end{array}$ \\
\hline $\begin{array}{l}77 \\
77 \\
77 \\
77 \\
74 \\
\end{array}$ & $\begin{array}{r}0 \\
+1 \\
-2 \\
0 \\
0 \\
\end{array}$ & $\begin{array}{l}42 \\
40 \\
43 \\
38 \\
46\end{array}$ & $\begin{array}{l}-3 \\
-3 \\
+3 \\
-1 \\
+1 \\
\end{array}$ & $\begin{array}{l}M \\
6.70 \\
6.79 \\
6.52 \\
M \\
\end{array}$ & $\begin{array}{c}\mathrm{M} \\
-0.20 \\
-0.35 \\
+0.11 \\
\mathrm{M} \\
\end{array}$ & $\begin{array}{l}6.99 \\
7.06 \\
7.25 \\
7.09 \\
7.12\end{array}$ & $\begin{array}{r}-0.39 \\
-0.36 \\
-0.56 \\
-0.33 \\
-0.31 \\
\end{array}$ & $\begin{array}{l}174 \\
249 \\
245 \\
177 \\
176\end{array}$ & $\begin{array}{r}+9 \\
-5 \\
-4 \\
+18 \\
+57 \\
\end{array}$ \\
\hline $\begin{array}{r}76 \\
\pm 1\end{array}$ & $\begin{array}{r}0 \\
\pm 1\end{array}$ & $\begin{array}{r}42 \\
\pm 3\end{array}$ & $\begin{array}{l}-1 \\
\pm 3\end{array}$ & $\begin{array}{r}6.67 \\
\pm 0.12\end{array}$ & $\begin{array}{l}-0.15 \\
\pm 0.23\end{array}$ & $\begin{array}{r}7.10 \\
\pm 0.10\end{array}$ & $\begin{array}{l}-0.39 \\
\pm 1.10\end{array}$ & $\begin{array}{r}206 \\
\pm 41\end{array}$ & $\begin{array}{l}+15 \\
\pm 25\end{array}$ \\
\hline $\begin{array}{r}77 \\
\pm 1\end{array}$ & & $\begin{array}{r}39 \\
\pm 3\end{array}$ & & $\begin{array}{r}6.69 \\
\pm 0.19\end{array}$ & & $\begin{array}{r}7.08 \\
\pm 0.08\end{array}$ & & $\begin{array}{r}198 \\
\pm 37\end{array}$ & \\
\hline
\end{tabular}

$\dagger$ Standard deviations.

$\ddagger$ Negative value obtained for brain intracellular water DMO concentration.

plasma and red cells approaching equilibrium after 5 hours.

As with the results after bicarbonate administration, negative values for brain intracellular DMO concentration were obtained when the chloride space was used as an estimate of brain ECF. The drop in DMO concentration in total brain water was responsible for this, rather than the slight increase in the chloride space of the brain. This observation is entirely independent of any assumptions concerning steady-state conditions or achievement of equilibria.

-Acid dogs. The results obtained after the infusion of $30 \mathrm{mEq}$ of $\mathrm{HCl}$ to 6 dogs were con- 
TABLE IV

Mean changes in acid-base relationships during the experimental period ( 5 hours -4 hours)

\begin{tabular}{|c|c|c|c|c|c|c|c|c|}
\hline & \multirow[b]{2}{*}{ No. dogs } & \multicolumn{4}{|c|}{ Plasma } & \multicolumn{3}{|c|}{ Brain } \\
\hline & & $\mathrm{pH}$ & $\mathrm{PcO}_{2}$ & $\mathrm{HCO}_{3}^{-}$ & DMO & $\mathrm{pH}_{\mathrm{i}}$ & $\mathrm{pH}_{\mathrm{i}} \mathrm{SO}_{4}$ & DMO \\
\hline & & $U$ & $m m \mathrm{Hg}$ & mmoles $/ L$ & $m g / L$ & $U$ & $i^{\circ}$ & $\begin{array}{l}m \mathrm{mg} / \mathrm{L} \text { total } \\
\text { brain } \mathrm{H}_{2} \mathrm{O}\end{array}$ \\
\hline $5 \%$ glucose in $\mathrm{H}_{2} \mathrm{O}$ & 7 & $\begin{array}{l}-0.07 \\
\pm 0.05\end{array}$ & $\begin{array}{l}+1 \\
\pm 5\end{array}$ & $\begin{array}{l}-1.1 \\
\pm 1.9\end{array}$ & $\begin{array}{l}-35 \\
\pm 23\end{array}$ & $\begin{array}{l}-0.18 \\
\pm 0.16\end{array}$ & $\begin{array}{l}-0.10 \\
\pm 0.07\end{array}$ & $\begin{array}{l}-29 \\
\pm 15\end{array}$ \\
\hline $\mathrm{NaHCO}_{3}^{-}$ & 6 & $\begin{array}{l}+0.31 \\
\pm 0.07\end{array}$ & $\begin{array}{l}+6 \\
\pm 1\end{array}$ & $\begin{array}{r}+21.3 \\
\pm 3.6\end{array}$ & $\begin{array}{l}+22 \\
\pm 12\end{array}$ & $\mathrm{M}^{*}$ & $\begin{array}{l}+0.10 \\
\pm 0.08\end{array}$ & $\begin{array}{l}-45 \\
\pm 25\end{array}$ \\
\hline Tris & 4 & $\begin{array}{l}+0.21 \\
\pm 0.06\end{array}$ & $\begin{array}{l}+1 \\
\pm 4\end{array}$ & $\begin{array}{r}+10.5 \\
\pm 4.8\end{array}$ & $\begin{array}{l}-24 \\
\pm 26\end{array}$ & $\mathrm{M}$ & $\begin{array}{l}-0.02 \\
\pm 0.17\end{array}$ & $\begin{array}{l}-78 \\
\pm 25\end{array}$ \\
\hline $\mathrm{HCl}$ & 6 & $\begin{array}{l}-0.27 \\
\pm 0.11\end{array}$ & $\begin{array}{l}-1 \\
\pm 4\end{array}$ & $\begin{array}{l}-5.5 \\
\pm 0.8\end{array}$ & $\begin{array}{r}-105 \\
\pm 43\end{array}$ & $\begin{array}{l}+0.29 \dagger \\
\pm 0.14\end{array}$ & $\begin{array}{l}-0.01 \\
\pm 0.03\end{array}$ & $\begin{array}{l}+37 \\
\pm 22\end{array}$ \\
\hline $10 \% \mathrm{CO}_{2}$ & 5 & $\begin{array}{l}-0.52 \\
\pm 0.30\end{array}$ & $\begin{array}{l}+60 \\
\pm 11\end{array}$ & $\begin{array}{l}+3.1 \\
\pm 0.8\end{array}$ & $\begin{array}{l}-86 \\
\pm 24\end{array}$ & $\begin{array}{l}-0.15 \dagger \\
\pm 0.23\end{array}$ & $\begin{array}{l}-0.39 \\
\pm 0.10\end{array}$ & $\begin{array}{l}+15 \\
\pm 25\end{array}$ \\
\hline
\end{tabular}

* Negative values obtained for brain intracellular water DMO concentration in each dog.

$\dagger$ Negative values obtained for brain intracellular water DMO concentration in some dogs.

sistent with the concept that hydrogen ion, like bicarbonate ion, does not equilibrate rapidly with brain water. Thus, mean plasma $\mathrm{pH}$ fell 0.27 $\pm 0.11 \mathrm{U}$, but brain $\mathrm{pH}_{\mathrm{i}} \mathrm{SO}_{4}$ fell only $0.01 \pm 0.03$ U. Plasma $\mathrm{PCO}_{2}$ did not change significantly. The decrease in hydrogen ion gradient produced by acid infusion was due to a rise in total brain water DMO of $37 \pm 22 \mathrm{mg}$ per L. Concurrently, plasma DMO fell $105 \pm 43 \mathrm{mg}$ per $\mathrm{L}$.

The rise in $\mathrm{pH}_{\mathrm{i}} \mathrm{Cl}$ of $0.29 \pm 0.14 \mathrm{U}$ would be explicable had plasma $\mathrm{PCO}_{2}$ fallen significantly, as it might have because of stimulation of ventilation by the acidosis. Since carbon dioxide, in contrast to hydrogen ion, passes rapidly across cell membranes, a fall in intracellular $\mathrm{PCO}_{2}$ would have accompanied the fall in plasma $\mathrm{PCO}_{2}$, and intracellular $\mathrm{pH}$ could, therefore, have risen rather than fallen. Such a paradoxical change in $\mathrm{pH}$ has been observed in the cerebrospinal fluid by Robin and associates (11), who accounted for it by this mechanism. However, ventilation of the dogs in the present study was kept constant so that plasma $\mathrm{PCO}_{2}$ did not fall significantly. Therefore, the paradoxical change in $\mathrm{pH}_{\mathrm{i}} \mathrm{Cl}$ that occurred after $\mathrm{HCl}$ infusion seems more likely to be merely a reflection of the inaccuracy of the chloride space as a measure of brain ECF. Thus, because of the relatively large drop in plasma $\mathrm{DMO}$ after infusion of $\mathrm{HCl}$, correction for brain chloride space DMO led to an abnormally high value for intracellular DMO.

Carbon dioxide dogs. Inhalation of $10 \% \mathrm{CO}_{2}$ for 1 hour by 5 dogs caused a rise in mean plasma $\mathrm{PCO}_{2}$ of $60 \pm 11 \mathrm{~mm} \mathrm{Hg}$ and a drop in

TABLE V

Effect of differences in magnitude of brain extracellular fluid on intracellular $p H$

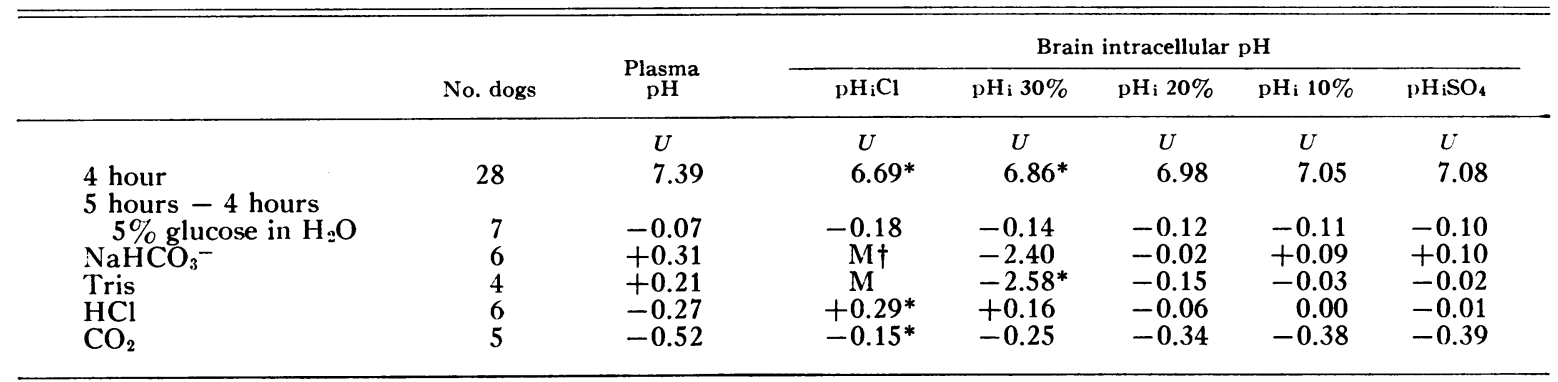

* Negative values obtained for brain intracellular water DMO concentration in some dogs.

$\dagger$ Negative values obtained for brain intracellular water DMO concentration in each dog. 
mean plasma $\mathrm{pH}$ of $0.52 \pm 0.30 \mathrm{U}$. Concurrently, mean $\mathrm{pH}_{\mathrm{i}} \mathrm{SO}_{4}$ fell $0.39 \pm 0.10 \mathrm{U}$, and $\mathrm{pH}_{\mathrm{i}} \mathrm{Cl}$ fell $0.15 \pm 0.23 \mathrm{U}$. Plasma bicarbonate concentration rose $3.1 \pm 0.8$ mmoles per $\mathrm{L}$ above a control level of $13.3 \pm 1.6$ mmoles per $\mathrm{L}$.

Effect of magnitude of brain ECF on intracellular $p H$. The values calculated for brain $\mathrm{pH}_{\mathrm{i}}$ based on 5 different estimates of brain ECF are shown in Table V. Included in this table are the data already presented for the sulfate and chloride spaces. The remaining data are based on assumed spaces of 10,20 , and $30 \%$ of brain water, arbitrarily selected to provide a full range of estimates of ECF between the extremes of the sulfate space on the one hand and the chloride space on the other. The data show that with a space of $30 \%$ or greater, negative values for intracellular DMO are obtained in many instances, and with a space of $20 \%$ or greater, paradoxical changes in the relationship between extracellular and intracellular $\mathrm{pH}$ occur, not only after $\mathrm{HCl}$ infusion, but also following $\mathrm{NaHCO}_{3}$ and Tris. These changes cannot be explained by any known mechanism.

\section{Discussion}

We recognize that the methods used in these studies have certain practical and theoretical limitations. The animals were subjected to a prolonged period of barbiturate anesthesia, and trauma to the brain was inevitable with the repeated biopsies. The hypotension seen in approximately $15 \%$ of the animals and the metabolic acidosis that developed in the dogs receiving $5 \%$ glucose in water are evidence that the condition of the preparation was by no means physiologic. Hyperventilation of the animals was necessary to maintain ECF $\mathrm{pH}$ at relatively normal values during control periods. The effects of whole body $\mathrm{CO}_{2}$ depletion produced by the hyperventilation may well have modified the values obtained for brain $\mathrm{pH}$ in these studies. From the theoretical standpoint, the many assumptions required to validate indicator methods for measuring intracellular $\mathrm{pH}$ dictate caution in interpreting results using such methods. These assumptions involve such problems as the absolute rate of equilibrium of the indicator system, the influence of the heterogeneity of intracellular wa- ter, the relative rate of equilibration of acid-base substances as compared to the rate of equilibrium of the indicator, the value of intracellular $\mathrm{pK}$, the question of intracellular activity of ions versus concentration, and the magnitude of the extracellular space of the tissue. These problems have been discussed elsewhere, and it is generally agreed that under appropriate circumstances an approximation to over-all intracellular $\mathrm{pH}$ can be made with these techniques $(1,2,5)$.

In the case of the brain, the problem of the magnitude of the brain extracellular space is especially perplexing, as there is no general agreement on this question, and a wide range of estimates for brain ECF have been obtained by different techniques. The chloride space as a measure of brain ECF is still accepted by some workers and was used recently by Woodbury, Koch, and Brodie $(4,13)$ in studies of brain intracellular $\mathrm{pH}$ in rats. Davson and Spaziani (6) found a chloride space of $32 \%^{5}$ for rat brain slices, but after washing out the specimens with a nitrate solution, $10 \%$ of the chloride remained in the tissue. These findings were interpreted as indicating that the upper limit of the true ECF is only $22 \%$, some $10 \%$ of the chloride being intracellular. Allen (14) measured the degree of diffusion of ferricyanide and inulin into rat brain slices and concluded that brain ECF was approximately $16 \%$. A number of in vivo physiologic techniques have given results in the range of $10 \%$. Streicher (15) found a thiocyanate space for rat brain of approximately $8 \%$, and Reed and Woodbury (16) reported a $\mathrm{C}^{14}$ sucrose space of rat brain of 9\%. Rall and Patlak (17) derived a figure of $10 \%$ for ECF in dogs, based on the degree of penetration of $\mathrm{C}^{14}$ inulin from the ventricular system into brain tissue. The data obtained relative to the magnitude of brain sulfate space appear to demonstrate the achievement of a steady state within 4 to 5 hours with respect to brain penetration by this ion. The plot of these data shows no discernible simple exponential increase in the value of the sulfate space with time, such as would be expected if equilibrium between plasma sulfate and brain sulfate had not been achieved. The tendency for the 12-hour spaces to be somewhat larger than

\footnotetext{
${ }^{5}$ All estimates of ECF quoted from the literature are expressed as percentage of wet weight of tissue.
} 
the 4-hour spaces may presumably be explained by slow penetration of brain water by this ion. These data are in close agreement with the data of Woodbury (7), who measured the kinetics of radiolabeled sulfate equilibration in rat brain. Using equations developed by Solomon (18), he determined that radiosulfate equilibrated with only $3.9 \%$ of the total brain volume during the first 16 hours after intraperitoneal injection. Subsequently the "sulfate space" increased, but this was attributed to "tissue binding" (intracellular penetration). Before the "binding" process occurred, the rate of uptake of sulfate could be resolved into a single component with a half time of 80 minutes. These data are also in close agreement with measurements of sulfate space in cats obtained by Barlow, Domek, Goldberg, and Roth (19), who injected $\mathrm{S}^{35} \mathrm{O}_{4}$ into ureter-ligated animals. These workers noted the achievement of a steady state of brain sulfate between 4 and 8 hours and found a sulfate space of 2 to $4 \%$ (wet weight) of brain at 6 hours. Electron micrographs of central nervous system tissue have revealed that most of the potential tissue space is occupied by cytoplasmic extensions of astrocytes and oligodendrocytes $(20,21)$, and estimates of ECF based on this appearance have ranged between 3 and $5 \%$.

The results obtained in these experiments demonstrate that, in the determination of brain intracellular $\mathrm{pH}$ by the DMO technique, not only are the absolute values for brain $\mathrm{pH}_{i}$ dependent upon the size of the ECF, but also upon the magnitude and, at times, the direction of change in $\mathrm{pH}_{i}$ brought about by modifications in extracellular $\mathrm{pH}$. These results suggest an upper limit to the size of the brain ECF. Thus, when the chloride space was used as an estimate of ECF, negative values for intracellular $\mathrm{DMO}$ were frequently obtained, so that $\mathrm{pH}_{i}$ could not be calculated. This was particularly true when the concentration of DMO in total brain water was decreased, as occurred after administration of $\mathrm{NaHCO}_{3}$ and Tris. These results do not depend on any assumptions concerning steady state or equilibrium circumstances. They clearly indicate that under these experimental circumstances there is no space present in brain tissue having the magnitude of chloride space and containing a con- centration of DMO experimentally found in ECF. From this aspect DMO serves as an extracellular marker independent of the fact that it distributes itself across cell membranes as a function of $\mathrm{H}^{+}$ratios. This same difficulty was encountered, although less frequently, when a space of $30 \%$ (23\% brain weight) was used in the calculation of $\mathrm{pH}_{i}$. Moreover, the changes in intracellular $\mathrm{pH}$ after infusion of $\mathrm{NaHCO}_{3}, \mathrm{HCl}$, and Tris observed with spaces of $20 \%$ or greater cannot be reconciled with known mechanisms. These results, therefore, suggest a brain ECF less than $20 \%$ of total brain water. This would mean that either the chloride concentration in brain extracellular water is much greater than in plasma, or that a portion of the chloride found in brain tissue is located intracellularly. Recently, Katzman (22) has proposed that glial cells are high sodium cells and has provided evidence in support of this hypothesis. He has found that, in acidic lipid extracts of brain, sodium predominates over potassium, indicating that sodium and potassium are not homogeneously distributed in brain but that there must be cellular elements with a high sodium concentration. In addition, analysis of glial tumors has revealed a high $\mathrm{Na}$ to $\mathrm{K}$ ratio, i.e., $1.8: 1$. Thus, the "space problem" in the central nervous system may be part of the unusual mechanism for control of fluid and electrolyte kinetics in this area.

In view of these considerations, it seems reasonable to assume that in this study the values obtained for $\mathrm{pH}_{\mathrm{i}} \mathrm{SO}_{*}$ are more representative of brain intracellular $\mathrm{pH}$ than are the results obtained for $\mathrm{pH}_{1} \mathrm{Cl}$. The control figure for brain $\mathrm{pH}_{\mathrm{i}} \mathrm{SO}_{4}$ of $7.08 \mathrm{U}$ is in close agreement with previous determinations of muscle and whole body intracellular $\mathrm{pH}$ by the DMO technique in the intact dog. Waddell and Butler (5) report a value of $7.04 \mathrm{pH} U$ for muscle, and Robin and associates (2), a figure of $7.08 \mathrm{pH} \mathrm{U}$ for whole body. The $\mathrm{pH}$ gradients between plasma and cells in these 3 studies were $0.31 \mathrm{pH} \mathrm{U}$ for brain, approximately $0.31 \mathrm{pH} \mathrm{U}$ for muscle, and 0.37 $\mathrm{pH} \mathrm{U}$ for whole body. A similar range of intracellular $\mathrm{pH}$ in muscle and nerve has been found with glass electrodes and by the $\mathrm{H}_{2} \mathrm{CO}_{3}-\mathrm{HCO}_{3}^{-}$ system (4). Recently, Brodie and Woodbury (13), using the latter system, found the intra- 
cellular $\mathrm{pH}$ of rat brain cortex to be $7.04 \mathrm{U}$, representing a cell to plasma gradient of $0.37 \mathrm{pH}$ $\mathrm{U}$. These results, however, were calculated on the assumption that the ECF was equivalent to the chloride space. Jasper and Erickson (23), using glass electrodes, obtained values of 7.15 to $7.35 \mathrm{U}$ for the $\mathrm{pH}$ of cat brain cortex.

The effects of $\mathrm{NaHCO}_{3}, \mathrm{HCl}$, and $\mathrm{CO}_{2}$ on brain intracellular $\mathrm{pH}$ are similar to the effects of these agents on the intracellular $\mathrm{pH}$ of a number of other tissues as determined by a variety of techniques (1). Of particular interest, however, are the recent reports of Waddell and Butler (5) on muscle $\mathrm{pH}$ and of Robin and his colleagues (2) on whole body $\mathrm{pH}$. Both studies were carried out on the intact dog utilizing the DMO technique. In a series of individual dog experiments, the former workers found that the intracellular $\mathrm{pH}$ of muscle increased only $0.04 \mathrm{U}$ when plasma $\mathrm{pH}$ was raised $0.26 \mathrm{U}$ by an infusion of $\mathrm{NaHCO}_{3}$. Similarly, muscle $\mathrm{pH}$ decreased only $0.13 \mathrm{U}$ when plasma $\mathrm{pH}$ was dropped $0.36 \mathrm{U}$ by $\mathrm{HCl}$. On the other hand, inhalation of $30 \% \mathrm{CO}_{2}$ caused a fall in plasma $\mathrm{pH}$ of $0.43 \mathrm{U}$ and a fall in muscle $\mathrm{pH}$ of $0.28 \mathrm{U}$. Robin and co-workers (2) reported that 1 hour after infusion of 150 mmoles $\mathrm{NaHCO}_{3}$, whole body intracellular $\mathrm{pH}$ rose only $0.03 \mathrm{U}$ at a time when plasma $\mathrm{pH}$ had increased $0.28 \mathrm{U}$. After the administration of $\mathrm{NaHCO}_{3}$, there was a substantial increase in brain $\mathrm{pH}$. This increase would have been somewhat larger had $\mathrm{PCO}_{2}$ not risen at the same time. These data suggest that either $\mathrm{HCO}_{3}{ }^{-}$penetrates brain water more rapidly than $\mathrm{H}^{+}$, that this compartment buffers $\mathrm{HCO}_{3}{ }^{-}$less efficiently than $\mathrm{H}^{+}$, or that some special process is responsible for $\mathrm{HCO}_{3}^{-}$transfer. This general finding has been reported by Relman, Adler, and Roy (24) in the isolated rat diaphragm. The apparent difference in the effect of Tris on intracellular $\mathrm{pH}$ in the brain and other tissues has been discussed above and may be related to the special properties of the brain as regards electrolyte transfers.

Previous studies concerned with changes in brain intracellular $\mathrm{pH}$ brought about by modifications in plasma $\mathrm{pH}$ have dealt largely with the effects of $\mathrm{CO}_{2}$. Employing the $\mathrm{H}_{2} \mathrm{CO}_{3}-\mathrm{HCO}_{3}-$ systems, Koch and Woodbury (4) found that brain $\mathrm{pH}$ dropped $0.06 \mathrm{U}$ when plasma $\mathrm{pH}$ was reduced $0.22 \mathrm{U}$ by maintaining rats in an atmosphere containing $12.5 \% \mathrm{CO}_{2}$ for 10 minutes. Results comparable to the present ones were obtained by Brodie and Woodbury (13) with the use of $30 \% \mathrm{CO}_{2}$ and an exposure time of 15 minutes. Under these conditions they found a reduction in rat brain $\mathrm{pH}$ of $0.28 \mathrm{U}$ with a fall in plasma $\mathrm{pH}$ of $0.46 \mathrm{U}$. Tschirgi (25) has measured the intracellular $\mathrm{pH}$ of rabbit cortex with glass electrodes and states that a fall in $\mathrm{pH}$ is affected by $\mathrm{CO}_{2}$ but not by $\mathrm{HCl}$. On the other hand, Jasper and Erickson (23), working with cats, and DeBareene, McCulloch, and Nims (26), working with monkeys, claim that cortical $\mathrm{pH}$, measured with glass electrodes, is similarly affected by $\mathrm{CO}_{2}$ and $\mathrm{HCl}$. The problems of measuring brain intracellular $\mathrm{pH}$ by means of hydrogen ion sensitive glass electrodes are considerable and, thus, interpretation of these data is difficult.

Although the difference in the ability of mineral acid and base on the one hand and carbon dioxide on the other to modify brain intracellular $\mathrm{pH}$ is understandable in terms of rates of penetration of charged particles across cell membranes, there exist other possible explanations. For example, active transport processes may conceivably maintain hydrogen ion gradients across cell membranes, or the buffering capacity may be different in intracellular water. Moreover, the duration of our observations was only 1 hour. The results obtained after mineral acid and base infusion may not reflect steady-state circumstances. Hence these particular data may be more qualitatively significant than quantitative in showing the relatively rapid penetration of brain water by $\mathrm{CO}_{2}$ as compared with $\mathrm{HCl}, \mathrm{NaHCO}_{3}$, and Tris. However, the necessary surgery and experimental maneuvers precluded studies of substantially longer duration. Had more time transpired, intracellular penetration of these ions might have been more complete. Future studies of chronic effects of acid-base substances on brain intracellular $\mathrm{pH}$ would certainly be worthwhile. In this regard, it is worth considering to what extent the present results might have been affected by failure of DMO to pass rapidly across cell membranes and, particularly, across the blood brain barrier. The DMO method for the measurement of intracellular $\mathrm{pH}$ is based on the assumption that the 
rate of diffusion of $\mathrm{HDMO}$ is much more rapid than the rate of diffusion of $\mathrm{DMO}^{-}$. As pointed out in the Results, changes in brain total DMO concentration are presumably accomplished by shifts of HDMO into or out of the cell. That such a shift can take place rapidly and to a considerable extent was particularly apparent after administration of $\mathrm{HCl}$, Tris, and $\mathrm{NaHCO}_{3}$. The rapid achievement of a steady state of DMO under control circumstances in brain is also reassuring in this respect. We emphasize that any error introduced by a slow equilibration rate of HDMO would influence the results with $\mathrm{NaHCO}_{3}$, Tris, and $\mathrm{HCl}$ infusion in a direction opposite from that obtained in these studies, i.e., intracellular $\mathrm{pH}$ would tend to change more in accordance with the magnitude of the change in plasma $\mathrm{pH}$ rather than less.

\section{Summary}

Measurements of brain intracellular $\mathrm{pH}$ under varying experimental conditions have been performed using the 5,5-dimethyl-2,4-oxazolidinedione (DMO) technique. These data indicate that there is a substantial hydrogen ion gradient between plasma and brain water. Acute changes in extracellular $\mathrm{pH}$ produced by the inhalation of $\mathrm{CO}_{2}$ gas are rapidly reflected in changes of $\mathrm{pH}$ in brain water, whereas acute changes in extracellular $\mathrm{pH}$ produced by $\mathrm{Na}$ $\mathrm{HCO}_{3}, \mathrm{HCl}$, and Tris infusion are not. The distribution of DMO between plasma and brain water suggests that the upper limit of brain extracellular fluid (ECF) is about $20 \%$ (about $14 \%$ calculated as percentage of brain weight) and, accordingly, that some of the brain chloride is intracellular.

\section{References}

1. Caldwell, P. C. Intracellular $\mathrm{pH}$. International Review of Cytology, G. H. Bourne and J. F. Danielli, Eds. New York, Academic Press 1956, vol. 5 , p. 229.

2. Robin, E. D., R. J. Wilson, and P. A. Bromberg. Intracellular acid-base relations and intracellular buffers. Ann. N. Y. Acad. Sci. 1961, 92, 539.

3. Robin, E. D., P. A. Bromberg, and R. J. Wilson. The determination of intracellular $\mathrm{pH}$ in normal human subjects. J. clin. Invest. 1961, 40, 1076.

4. Koch, A., and D. M. Woodbury. Carbonic anhydrase inhibition and brain electrolyte composition. Amer. J. Physiol. 1960, 198, 434.
5. Waddell, W. J., and T. C. Butler. Calculation of intracellular $\mathrm{pH}$ from the distribution of 5,5-dimethy1-2,4-oxazolidinedione (DMO). Application to skeletal muscle of the dog. J. clin. Invest. 1959, 38, 720 .

6. Davson, H., and E. Spaziani. The blood-brain barrier and the extracellular space of brain. J. Physiol. 1959, 149, 135.

7. Woodbury, D. M. Fine structure of the neuropil in relation to neuroglia cells (round table discussion) in Biology of Neuroglia, W. F. Windle, Ed. Springfield, Ill., Charles C Thomas, 1958, ch. 7, p. 120.

8. Butler, T. C. Quantitative studies of the demethylation of trimethadione (Tridione). J. Pharmacol. exp. Ther. 1953, 108, 11.

9. Cotlove, E., H. V. Trantham, and R. L. Bowman. An instrument and method for automatic, rapid, accurate, and sensitive titration of chloride in biologic samples. J. Lab. clin. Med. 1958, 51, 461.

10. Davson, H. Physiology of the Ocular and Cerebrospinal Fluids. Boston, Little, Brown, 1956.

11. Robin, E. D., R. D. Whaley, C. G. Crump, A. G. Bickelmann, and D. M. Travis. Acid-base relations between spinal fluid and arterial blood with special reference to control of ventilation. J. appl. Physiol. 1959, 13, 385.

12. Nahas, G. G. The pharmacology of Tris (hydroxymethyl) aminomethane (Tham). Pharmacol. Rev. 1962, 14, 447.

13. Brodie, D. A., and D. M. Woodbury. Acid-base changes in brain and blood of rats exposed to high concentrations of carbon dioxide. Amer. J. Physiol. 1958, 192, 91.

14. Allen, J. N. Extracellular space in the central nervous system. Arch. Neurol. Psychiat. (Chic.) 1955, 73, 241.

15. Streicher, E. The thiocyanate space of rat brain in experimental cerebral edema. J. Neuropath. exp. Neurol. 1962, 21, 437.

16. Reed, D. J., and D. M. Woodbury. Kinetics of $\mathrm{C}^{14}$ sucrose distribution in cerebral cortex, cerebrospinal fluid, and plasma of rats. Fed. Proc. 1960, 19,80 .

17. Rall, D. P., and C. S. Patlak. Extracellular space in brain. Fed. Proc. 1962, 21, 324.

18. Solomon, A. K. Equations for tracer experiments. J. clin. Invest. 1949, 28, 1297.

19. Barlow, C. F., N. S. Domek, M. A. Goldberg, and L. J. Roth. Extracellular brain space measured by $\mathrm{S}^{35}$ sulfate. Arch. Neurol. (Chic.) 1961, 5, 102.

20. Wyckoff, R. W. G., and J. Z. Young. The motorneuron surface. Proc. roy. Soc. B 1955-56, 144, 440.

21. Gerschenfeld, H. M., F. Wald, J. A. Zadunaisky, and E. D. P. DeRobertis. Function of astroglia in the water-ion metabolism of the central nervous system. Neurology (Minneap.) 1959, 9, 412. 
22. Katzman, R. Electrolyte distribution in mammalian central nervous system. Neurology (Minneap.) 1961, 11, 27.

23. Jasper, H., and T. C. Erickson. Cerebral blood flow and $\mathrm{pH}$ in excessive cortical discharge induced by metrazol and electrical stimulation. J. Neurophysiol. 1941, 4, 333.

24. Relman, A., S. Adler, and A. Roy. Intracellular acid-base equilibrium: The reaction of muscle cells to "metabolic" and "respiratory" changes in extracellular activity. Trans. Ass. Amer. Phycns 1963, 76, 176.

25. Tschirgi, R. D., and J. L. Taylor. Slowly changing bioelectric potentials associated with the bloodbrain barrier. Amer. J. Physiol. 1958, 195, 7.

26. DeBarenne, D., W. S. McCulloch, and L. F. Nims. Functional activity and $\mathrm{pH}$ of the cerebral cortex. J. cell. comp. Physiol. 1937, 10, 277.

\section{SPECIAL NOTICE TO SUBSCRIBERS}

Post Offices will no longer forward the Journal when you move.

Please notify The Journal of Clinical Investigation, Business Office, 10 Stoughton Street, Boston, Mass. 02118, at once when you have a change of address and do not omit the Zip Code number. 